\title{
PENERAPAN MATERIAL KACA DALAM ARSITEKTUR
}

\author{
Lestari'; M. Ridha Alhamdani ${ }^{1}$ \\ ${ }^{1}$ Program studi Arsitektur, Fakultas Teknik Universitas Tanjungpura, Indonesia \\ lest_tazkiya@yahoo.com
}

\begin{abstract}
ABSTRAK
Kaca telah dikenal sejak ribuan tahun dan merupakan bahan buatan manusia yang cukup tua. Penggunaannya sebagai bahan bangunan meluas sejak abad ke 17 terutama setelah perang dunia kedua. Arsitektur kaca menjadi suatu kecenderungan dari desain-desain bangunan di dunia sejak abad ke-20. Material ini dianggap sangat relevan dengan konsepkonsep yang ada. Kaca digunakan sebagai material ornamen, bukaan atau jendela, material kulit bangunan, sampai pada material struktur bangunan. Sifat kaca yang transparan, simple, dan bersih menjadikan material ini menguntungkan untuk mendukung konsep yang digunakan. Tulisan ini memaparkan penggunaan kaca sebagai bahan bangunan, baik sebagai bahan ornamen, kulit bangunan atau struktur bangunan, maupun sebagai pendukung konsep arsitektur khususnya konsep transparansi. Dipaparkan pula mengenai sifat-sifat teknis dari bahan kaca sebagai pertimbangan dalam pemilihan bahan bangunan.
\end{abstract}

Kata kunci : arsitektur, material, kaca

\begin{abstract}
Glass has been known for thousands of years and is a man made material that is quite old. Extends its use as building material since the 17 century, especially after the second world war. Glass architecture become a trend of buiding designs in the world since 20th century. This material relevant to the existing concepts. Glass is used as an ornament material, window, the building skin materials, and the building structure materials. Glass properties that transparent, simple and clean make this material support the concepts used. This paper describes the use of glass as a building material, either as a ornament, the building skins, the building structures, and the building concepts expecially transparency concept. This paper also present the technical properties of glass as a building material.
\end{abstract}

Keywords : architecture, material, glass

\section{Pendahuluan}

Kaca merupakan material yang sudah lama dikenal, bahkan sejak ribuan tahun yang lalu. Penggunaannya sebagai bahan bangunan mulai dikenal sejak abad ke-17. Pada abad ke-20 penggunaan kaca pada bangunan didukung oleh perkembangan industrialisasi dan penemuan teknologi dalam pengolahan dan produksi kaca. Kecenderungan desain dengan meminimalkan ornamen pada abad tersebut juga mendukung penggunaaan material kaca. Penggunaan kaca tetap menjadi pilihan dari bangunan-bangunan di era abad 21. Selain peningkatan pengetahuan akan sifat-sifat bahan ini yang transparan, mampu memberikan pencahayaan dan panas pada bangunan, perkembangan proses produksi kaca, menyebabkan penggunaan material ini semakin luas dan digunakan hampir di seluruh bagian bangunan.

\section{Sejarah Kaca dalam Arsitektur}

Proses pembuatan kaca saat ini telah berkembang pesat. Semula kaca yang digunakan sebagai bahan bangunan hanya berupa kaca flat, namun sekarang telah berkembang dengan berbagai bentuk sesuai dengan kebutuhan sebagai bahan bangunan. Menurut Staib (1999), beberapa periode dalam perkembangan penggunaan kaca adalah sebagai berikut:

\section{Sebelum Abad Ke 17}

Kaca telah dikenal sejak ribuan tahun 
yang lalu, namun tidak ada yang bisa memastikan kapan dan dari mana kaca pertama mulai dibuat dan digunakan. Sejak zaman Mesopotamia dan Egypt, kaca sudah dikenal, namun penggunaannya masih terbatas sebagai peralatan rumah tangga dan perhiasan/perabot.Pengunaan pada bangunan masih terbatas pada bangunan gereja dan biara (gambar 1).

\section{Pada abad ke 17-19}

Kaca mulai banyak digunakan sebagai bahan bangunan sejak abad ke 17. Di abad ke 18 dan 19 penggunaannya meluas untuk bangunan-bangunan privat dan publik.

\section{Pada abad ke 20-21}

Seiring dengan perkembangan proses produksi kaca dan gaya arsitektur yang berkembang, kaca menjadi bahan yang sangat banyak digunakan dalam bangunan pada abad ke 20. Tidak hanya sebagai orneman namun digunakan pada hampir seluruh bagian bangunan, seperti dinding, atap maupun sebagai struktur. (Gambar 2)

\section{Kaca sebagai Material Bangunan}

Kaca merupakan bahan anorganik yang dapat memiliki sifat jernih, tembus cahaya atau berkilau. Sifat paling menonjol dari suatu jenis kaca tergantung jumlah unsur pembentuknya.

\section{Jenis kaca dan Penerapannya dalam Arsitektur}

Saat ini jenis kaca sangat beragam diproduksi sesuai dengan penggunaannya dalam bangunan.

Menurut Garg (2007), jenis kaca yang penting dan sering digunakan sebagai bahan bangunan dapat dikelompokkan sebagai berikut :

a. Kaca Normal (Annealed Glass).

Kaca normal merupakan kaca datar dengan permukaan jernih dan tingkat distorsi yang rendah.

Kaca normal biasa digunakan untuk aplikasi pada bangunan perumahan, shoppingmall, hotel atau restoran. Penggunaannya untuk bagian bangunan seperti jendela, pintu, dinding partisi, display, atrium, railing, green house dll.

Berapa tipe dari kaca normal adalah :
- Clear Glass, merupakan kaca yang jelas dan transparan yang memberikan bayangan objek dibelakangnya dengan sangat jelas.

- Tinted Glass, merupakan kaca yang telah diberi tambahan oksidan dari suatu jenis metal tertentu untuk mengurangi efek silau terhadap mata

- Patterned, figured or rolled glass, merupakan jenis kaca dekoratif yang tembus pandang dengan pola tertentu disalahsatu permukaannya agar terjadi penyebaran cahaya yang datang pada permukaan kaca. Banyak digunakan pada interior bangunan

- Wire glass, merupakan kaca yang diproduksi untuk perlindungan terhadap kebakaran

- Extra clear glass, merupakan jenis kaca yang digunakan untuk tujuan estetika atu privasi karena dapat melindungi objek dibagian belakang dengan permukaan yang sangat halus.

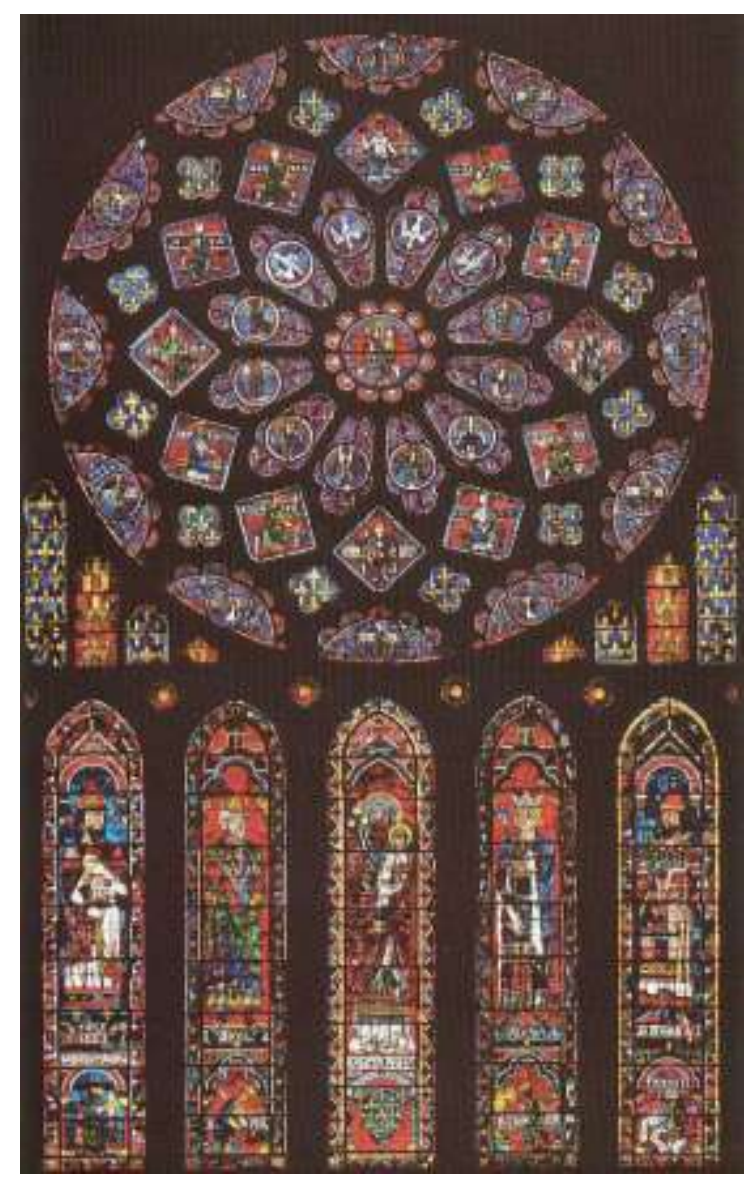

Sumber : (Staib, 1999)

Gambar 1. Penggunaan ornament kaca pada jendela Chartres Catedral 


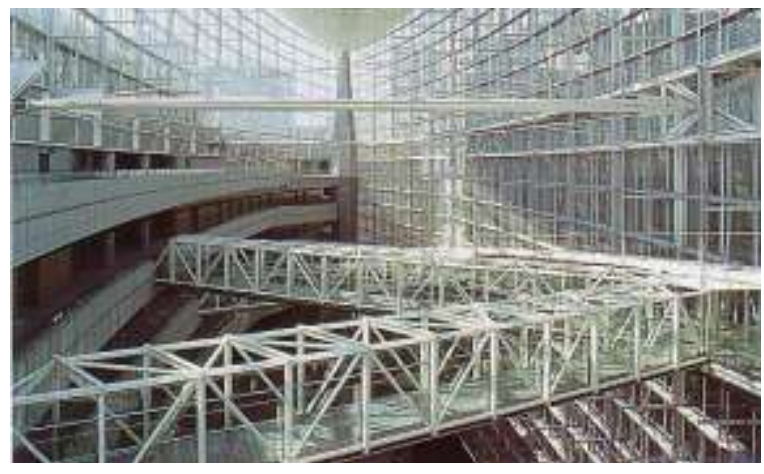

Sumber : (Staib, 1999)

Gambar 2. Penggunaan kaca pada Tokyo Forum, Tokyo, Rafael Vinaly, 1997

\section{b. Kaca laminasi (Laminated Glass)}

Kaca laminasi merupakan kaca yang terdiri dari 2 atau lebih lapisan dengan satu atau lebih lapisan transparan dengan penambahan bahan plastic Polyvinyl butiral [PVB] diantara kedua lapisannya. Sifat kaca diperkuat dengan adanya lapisan PVB.

Aplikasi penggunaan kaca laminasi antara lain untuk bangunan perkantoran, bank, museum, toko perhiasan dll. Penggunaannya untuk bagian bangunan seperti atap (gambar 3), lantai, skylight, ruang observatorium hewan, akuarium, pelindungan terhadap gempa dan angin kecepatan tinggi dan kepentingan akustik. lain :

Kelebihan dari kaca laminasi ini antara

- Dapat mengurangi resiko retakan/pecah, bahkan dapat mengamankan gedung dari peluru, benda berat atau ledakan kecil. Walaupun terjadi kerusakan atau pecah, jenis kaca ini tetap memberi keamanan terhadap penghuni karena tetap berada pada posisinya (tidak terpecah menjadi puing-puing) seperti terlihat pada gambar 4 .

- Penghalang yang baik terhadap kebisingan.

- Dapat mengurangi masuknya sinar ultraviolet ke dalam bangunan. Perlindungan terhadap sinar ultraviolet bahkan mencapai $99 \%$.

- Mengurangi resiko pecahan puing akibat bencana seperti gempa, angin kencang , atau badai

- Dapat memepertahankan waran dan umur bangunan

- Mengurangi kerusakan akibat panas

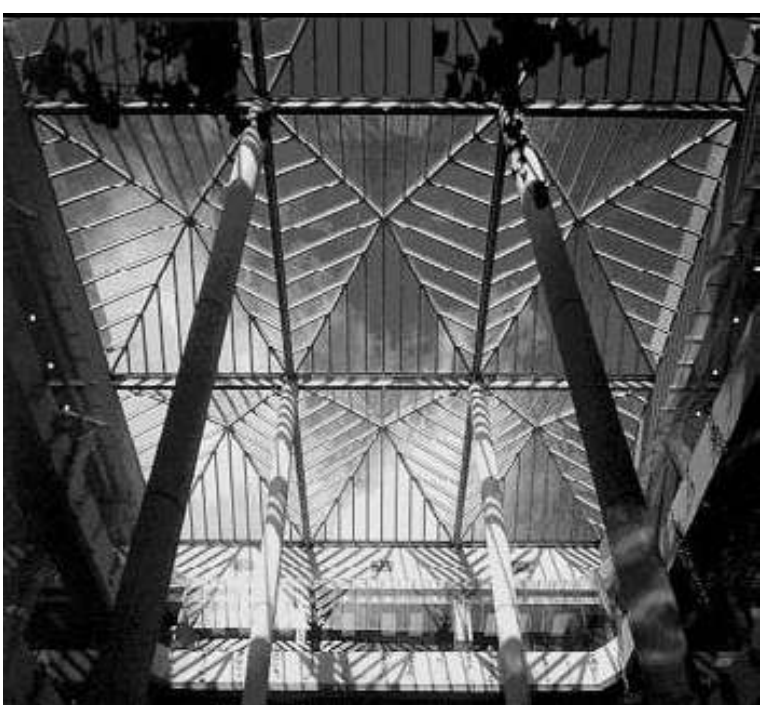

Sumber : (Garg, 2007)

Gambar 3. Penggunaan laminated glass pada atap bangunan
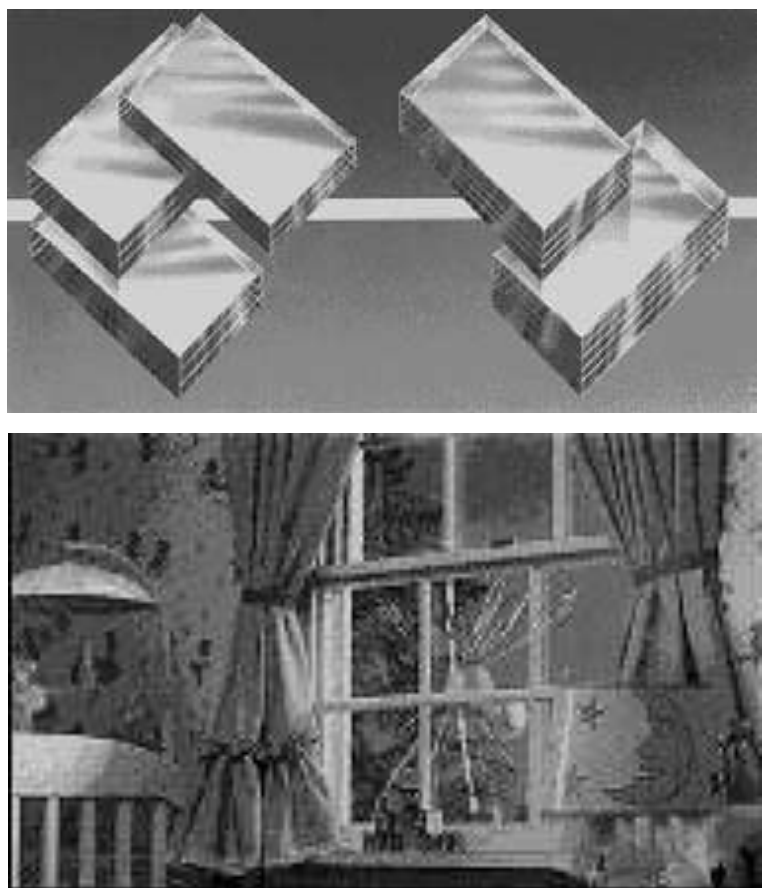

Sumber : (Garg, 2007)

Gambar 4. Laminated glass dan penggunaannya untuk perlindungan terhadap resiko pecah

\section{c. Tempered or Toughened Glass}

Tempered glass merupakan kaca yang sangat kuat yang diproduksi dengan perlakuan pemanasan seragam pada suhu sekitar $6500 \mathrm{C}$ yang kemudian didinginkan dengan cepat. 
Kelebihan dari jenis kaca ini adalah :

- Sulit untuk pecah, walaupun pecah, akan menjadi bagian-bagian yang sangat kecil sehingga tidak membahayakan penghuni.

- Lebih kuat 4-5 kali dari kaca normal dengan ketebalan yang sama

- Sangat kuat terhadap perubahan suhu mencapai 2500 C, dibandingkan kaca normal yang hanya dapat bertahan pada perubahan suhu $400 \mathrm{C}$.

Tempered glass umumnya digunakan untuk aplikasi pada bangunan-bangunan dengan iklim yang keras misalnya dengan angin yang kencang atau beban salju dan termal yang tinggi. Digunakan untuk tujuan keamanan dan kekuatan, pada dinding bangunan-bangunan tinggi, airport atau untuk penggunaan interior dan eksterior yang memerlukan kekuatan tinggi (gambar 5).

d. Heat strengthened glass.

Heat strengthened glass merupakan jenis tempered glass yang diperkuat secara termal dengan menginduksi tekanan permukaan. Jenis kaca ini banyak digunakan untuk aplikasi pada dinding pemisah, lantai, atap dan kaca struktural. Kaca ini memiliki kekuatan mekanik 2 kali dibandingkan tempered glass biasa. Lebih tahan terhadap kerusakan akibat suhu dan pengurangan terhadap distorsi.

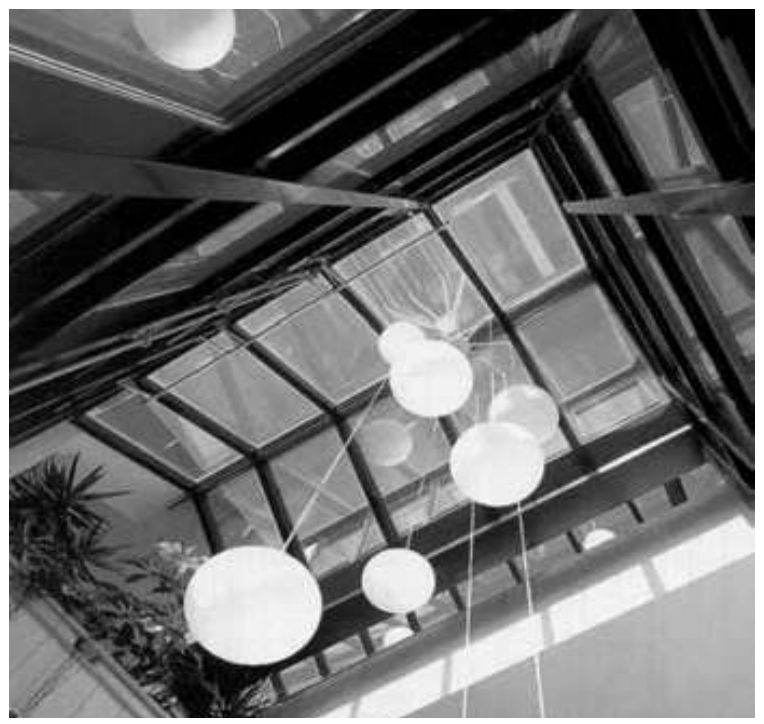

Sumber : (Garg, 2007)

Gambar 5. Penggunaan tempered glass pada bangunan e. Heat Soaked Tempered Glass

Heat Soaked Tempered Glassm erupakan jenis kaca yang diproduksi dengan teknik perendaman untuk mengurangi resiko kerusakan yang diakibatkan proses produksi. Jenis kaca ini banyak digunakan untuk aplikasi pada bagian bangunan yang memerlukan kekuatan terhadap perubahan temperature, sepeti kaca struktural.

f. Kaca reflektif (Reflective glass)

Kaca reflektif merupakan kaca yang dilapisi logam pada salah satu nya untuk meningkatkan reflesi panas dan cahaya. Jenis kaca ini memiliki kelebihan pada estetikanya dan mengurangi panas dan silau pada eksterior bangunan. Jenis kaca ini juga dapat mengurangi beban AC. Salah satu jenis reflective glass adalah kaca reflektif surya yang dapat merefleksi cahaya tanpa mengurangi sifat transparansi pada kaca tersebut. Penggunaan kaca reflektif misalnya pada entrance bangunan, pada jendela untuk ruang-ruang privat, dinding dekoratif, fasad bangunan dan pada bagian lain yang memerlukan perlindungan terhadap cahaya matahari.

\section{g. Insulating Glass Unit (Double Glazing)}

Insulating Glass Unit merupakan jenis kaca pabrikasi yang terbuat dari 2 atau lebih kaca panel dengan rongga udara diantara lapisan kacanya. Rongga ini bisa diisi dengan udara kering atau gas agar memiliki kinerja termal lebih baik. Sistem seperti ini memiliki kelebihan karena dapat mengurangi transmisi panas dibandingkan kaca normal. Kelebihan kaca insulasi ini dapat mengurangi panas pada bangunan sehingga mengurangi beban pendinginan. Selain ini sangat efektif dalam mengurangi tingkat kebisingan yang berasal dari eksterior.

Aplikasi kaca ini adalah untuk bangunan kantor, rumah sakit, hotel rumah dan bangunan-bangunan lain yang memerlukan pemanasan atau pendinginan yang tinggi. Termasuk bangunan yang memerlukan tingkat insulasi suara.

h. Cermin atau Mirror

Cermin merupakan jenis kaca reflektif dengan tingkat refleksi yang tinggi. Dapat memberikan bayangan pada objek di depannya. Penggunaannya pada bangunan seperti pada kamar mandi, ruang ganti atau 
dinding dekoratif.

\section{Sifat Transmisi, Refleksi dan Absorbsi Kaca}

Kaca tidak sepenuhnya transparan, karena sebagian cahaya yang jatuh akan direfleksikan dan sebagian akan diserap oleh warna kaca. Perbandingan sifat transmisi, refleksi dan absorbsi kaca dibandingkan dengan bahan bangunan lain dapat dilihat pada gambar 8. Transmisi cahaya yang melewati kaca, sebagian diubah ke energi lain, umumnya ke dalam energi panas. Perubahan energinya tergantung dari ketebalan kaca. Sifat ini terkadang dianggap merugikan misalnya pada kasus kaca jendela, karena menimbulkan panas pada ruangan. Hal ini karena kaca juga merupakan pemancar radiasi yang baik pada kisaran cahaya tampak, yang memiliki intensitas tertinggi, lebih dari 50\% cahaya matahari (gambar 6)

\section{Sifat Akustik dan Termal Kaca}

Kaca umumnya memiliki konduktivitas termal yang tinggi. Hal ini dapat dikurangi dengan kaca insulasi panas yaitu dengan menyediakan rongga gas pada 2 lapisan kaca.

Kaca menyerap dan memantulkan suara tergantung dari panjang gelombang suara. Kaca dengan permukaan halus dapat merugikan secara akustik. Namun hal ini dapat dikurangi dengan memberikan tekstur pada permukaan kaca serta meningkatkan ketebalan dan massa dari kaca. Hubungan antara ketebalan kaca dan sound reduction dapat dilihat pada gambar 7 .

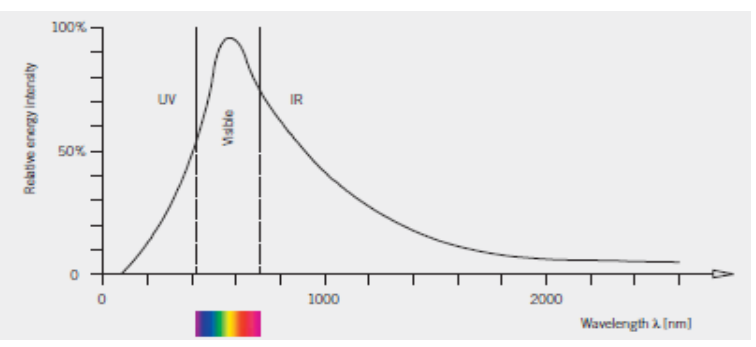

Sumber : (Wurm, 2007)

Gambar 6. Spektrum cahaya matahari yang dapat jatuh pada permukaan kaca

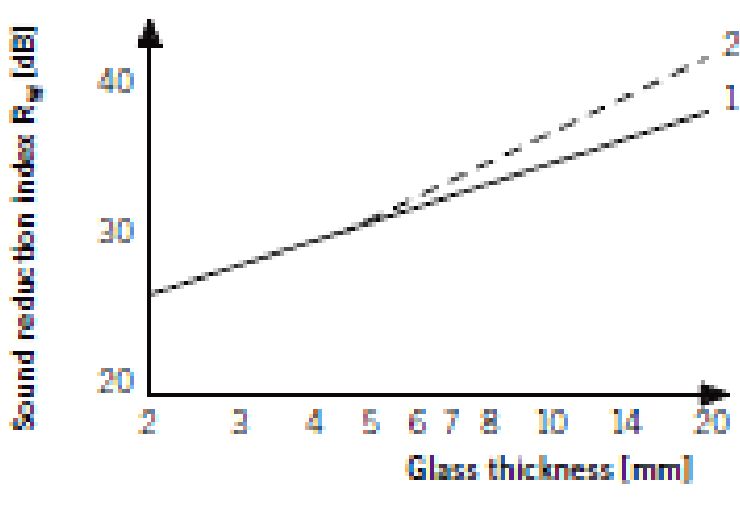

Sumber : (Wurm, 2007)

Gambar 7. Grafik hubungan antara ketebalan kaca dan sound reduction 


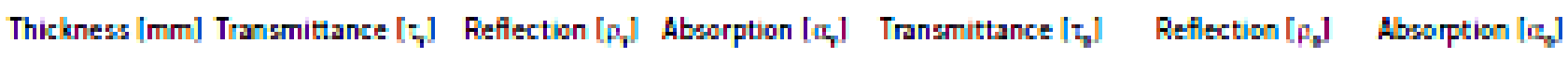

\begin{tabular}{|c|c|c|c|c|c|c|}
\hline 2 & 91 & a & ] & $\mathrm{ET}$ & a & 5 \\
\hline 3 & 91 & a & ] & 84 & 7 & 5 \\
\hline 4 & 90 & 름 & 2 & $\mathrm{E}$ & 7 & 11 \\
\hline$E_{1}$ & 90 & a & 2 & 50 & 7 & 13 \\
\hline 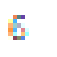 & 로 & a & 3 & $7 \mathrm{E}$ & 7 & LE \\
\hline a & $\mathrm{gs}$ & a & 3 & 74 & 7 & 15 \\
\hline 10 & as & a & 4 & $T 1$ & 7 & $z$ \\
\hline 12 & ac & a & 5 & 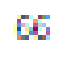 & 5 & 28 \\
\hline 15 & as & a & 9 & $E$ & $\mathbf{E}$ & 3 \\
\hline
\end{tabular}

Sumber : (Wurm, 2007)

Gambar 8. Transmisi, Refleksi dan Absorbsi kaca pada beberapa jenis ketebalan

\section{Pembahasan: Aplikasi Material Kaca Pada Bangunan}

Dengan berbagai jenis dari produksi kaca, penerapan dapat diaplikasikan pada hampir semua bagian bangunan.

\section{Kaca sebagai atap bangunan}

Sifat dan ketersediaan bahan bangunan menjadi aspek pertimbangan dalam perencanaan atap bangunan. Penggunaan atap kaca muncul di era industrialisasi karena kebutuhan akan atap transparan pada pabrik dan ruang-ruang besar seperti terminal kereta api. Beberapa tipe atap kaca dapat dilihat pada diagram gambar 10 .

Selain sebagai pelindung, penggunaan atap kaca umumnya memiliki fungsi sebagai pencahayaan (skylight). Struktur atap kaca harus mampu dibuat dengan sistem yang utuh sehingga dapat menahan beban-beban yang ditimpakan kepada struktur.

Peranan bentuk dan dimensi sangat menentukan kekuatan dari atap kaca.
Beberapa contoh penggunaan atap kaca dapat dilihat pada gambar 9. pencahayaan (skylight). Struktur atap kaca harus mampu dibuat dengan sistem yang utuh sehingga dapat menahan beban-beban yang ditimpakan kepada struktur.

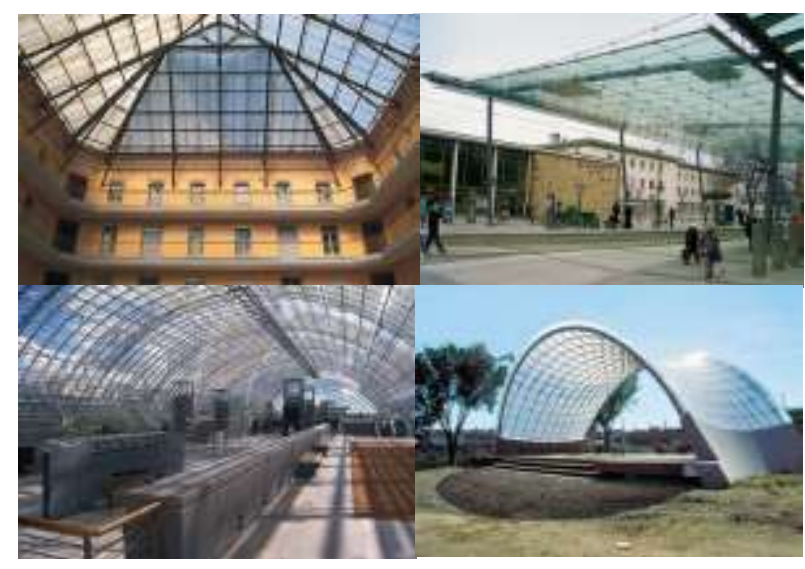

Sumber : (Wurm, 2007)

Gambar 9. Beberapa aplikasi bentuk atap kaca pada bangunan 


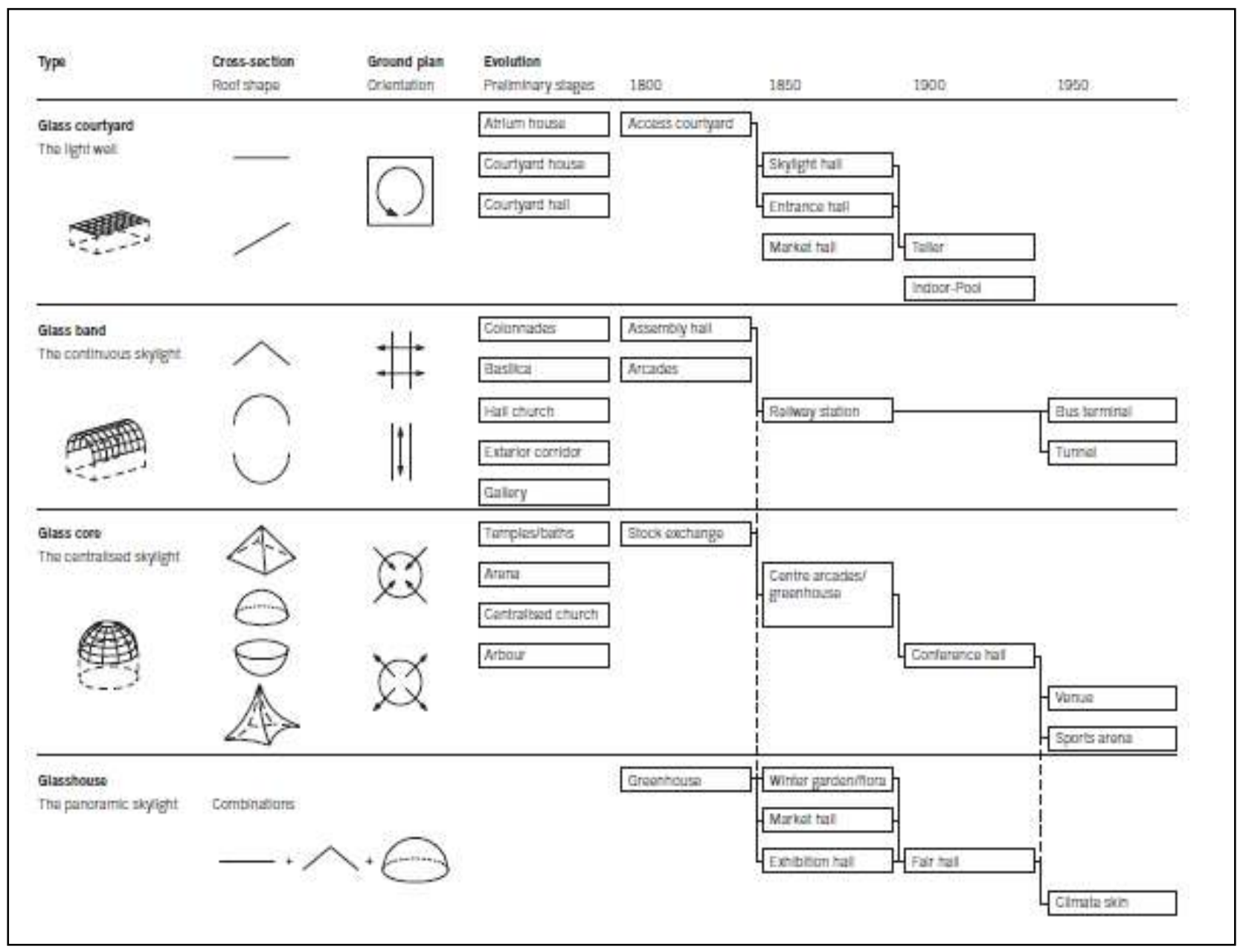

Sumber : (Wurm, 2007)

Gambar 10. Transmisi, Refleksi dan Absorbsi kaca pada beberapa jenis ketebalan

\section{Kaca sebagai dinding bangunan}

Kaca sebagai bahan yang memiliki ketahanan yang tinggi terhadap bahan kimia dan pengaruh korosi serta memiliki sifat tranparansi yang tinggi, sangat cocok digunakan sebagai bahan kulit bangunan. Hanya silika (larutan hydrofluoric acid) yang dapat menyerang permukaan kaca sehingga menyebabkannya menjadi terlihat buram. Larutan basa yang mungkin timbul dari beton berdekatan atau dari bahan kapur pada bagian bangunan lain juga dapat merusak permukaan kaca. Akan tetapi, kaca memiliki kelebihan dengan sifat-sifat sebagai bahan akustik yang baik serta memiliki sifat optik dan ketahanan yang tinggi terhadap temperatur sehingga cocok untuk digunakan sebagai elemen penutup bangunan.
Sifat-sifat teknis yang dapat dibentuk dari bahan kaca seperti insulasi panas, bahan akustik dan transmisi cahaya dapat dimanfaatkan untuk mendapatkan kenyamanan dalam bangunan. Penggunaan kaca harus disesuaikan dengan kebutuhan dalam bangunan dan tipe/jenis kaca seperti bangunan yang memerlukan tingkat insulasi panas atau kualitas akustik yang baik.

Selain pemilihan tipe kaca yang tepat, sambungan merupakan hal yang paling penting untuk diperhatikan dalam instalasi kaca sebagai dinding bangunan. Kekuatan dapat berkurang atau bertambah pada sambungan tersebut. Beberapa tipe sambungan yang digunakan pada kaca dinding bangunan dapat dilihat pada gambar-gambar 11 dan gambar 12 . 


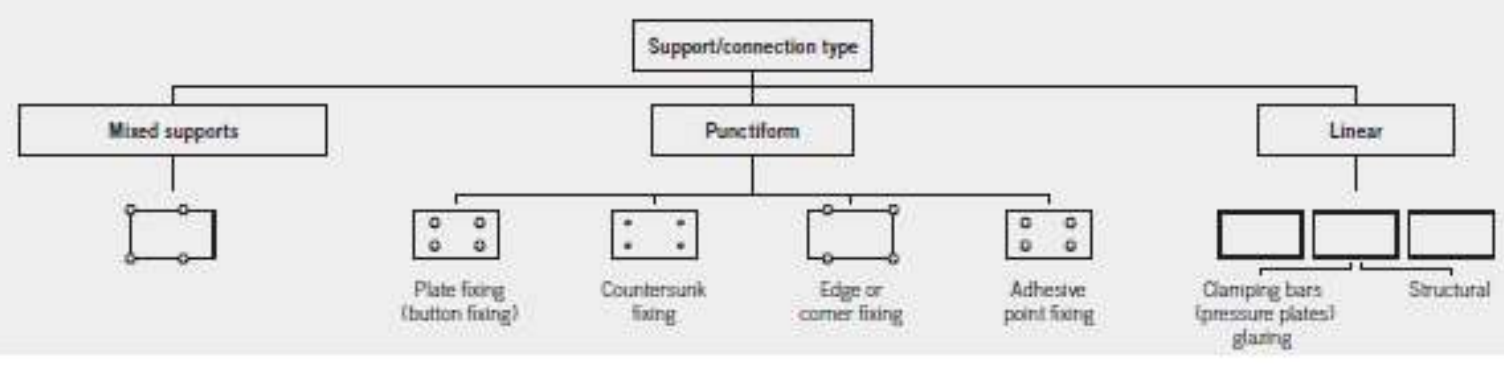

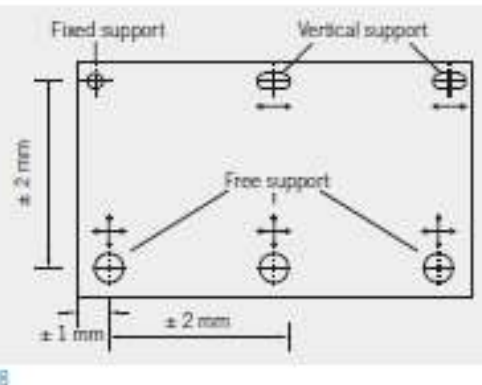

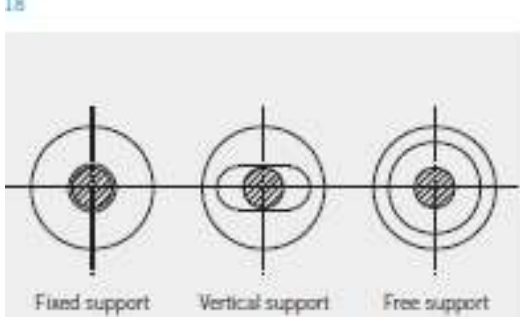

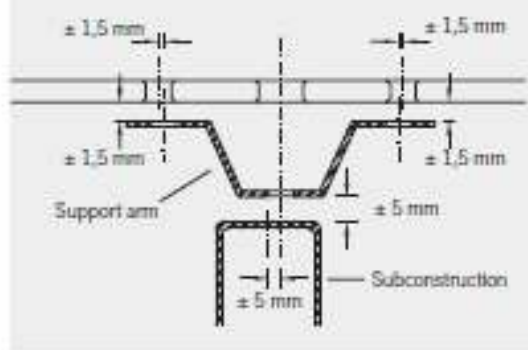

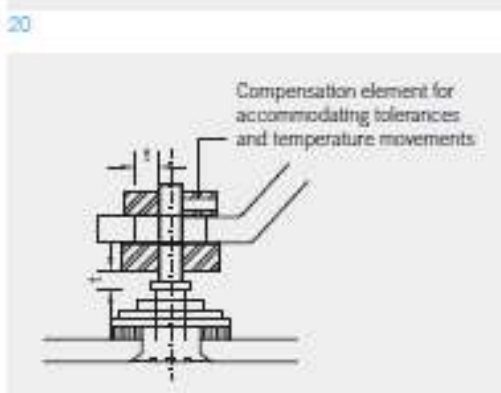

Sumber : (Wurm, 2007)

Gambar 11. Tipe konektor pada kaca sebagai kulit bangunan
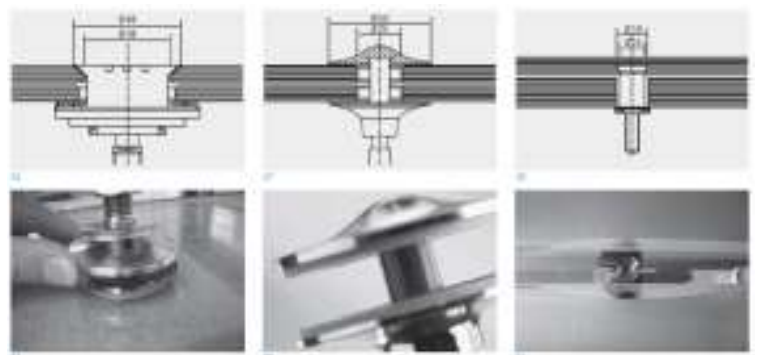

Sumber : (Wurm, 2007)

Gambar 12. Detail sambungan kaca

Bentuk bangunan menjadi penentu dalam kesuksesan pemilihan kaca pada kulit bangunan. Selain memiliki efek terhadap termal dan akustik, kaca merupakan bahan yang dapat memberikan estetika pada bangunan. Pemilihan bentuk dan penempatan material kaca dapat memberikan efek visual yang sangat baik pada bangunan. Contoh aplikasi bahan kaca pada bangunan dapat dilihat pada gambar 13.

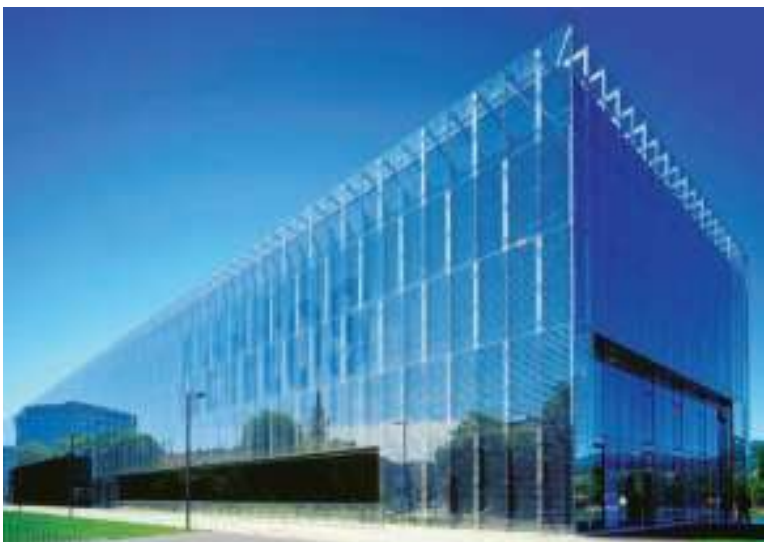

Sumber : (Wurm, 2007)

Gambar 13. Aplikasi kaca pada penutup dinding bangunan

\section{Kaca sebagai struktur bangunan}

Kaca tidak hanya dapat difungsikan sebagai elemen arsitektural bangunan namun dapat pula berfungsi sebagi elemen struktural bangunan. Kaca dapat difungsikan sebagai penerima beban-beban 
pada bangunan. Kekuatan dapat berasal dari bahan kaca sendiri dengan perkuatan dari bentuk struktur dan sambungan. Aplikasi kaca sebagai struktur dapat dilihat pada gambar 14.

Bahan kaca dapat memberikan bentuk struktur seperti yang dibentuk oleh material lain. Perbandingan sifat mekanik kaca dibandingkan bahan lain dapat dilihat pada gambar 15. Struktur seperti portal, frame, arch, shell, space frame dan bentuk struktur lain dapat menggunakan bahan kaca (lihat gambar 16).

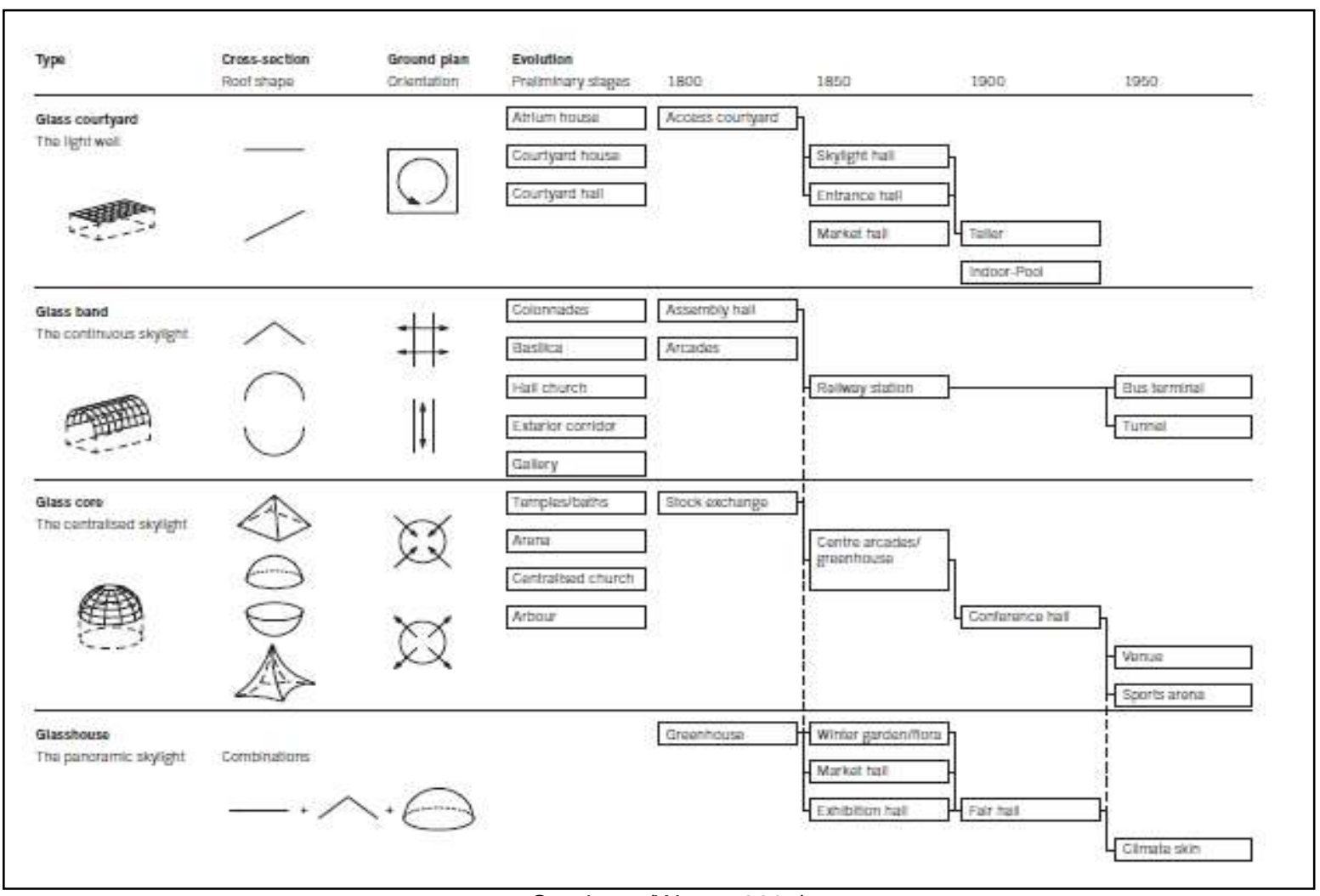

Sumber: (Wurm, 2007)

Gambar 14. Aplikasi kaca sebagai struktur bangunan

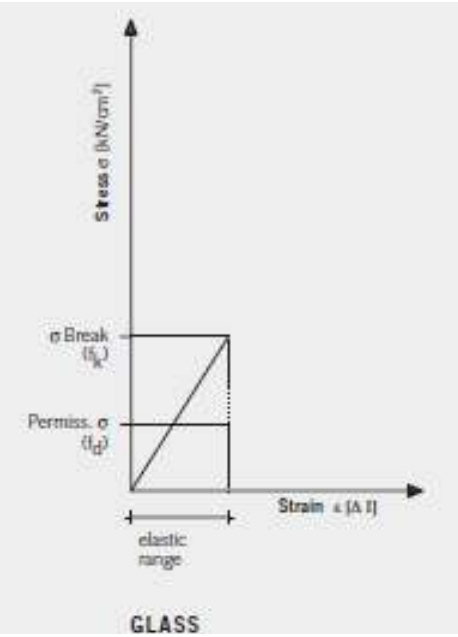

Sumber : (Wurm, 2007)
Gambar 15. Grafik sifat mekanik kaca diband

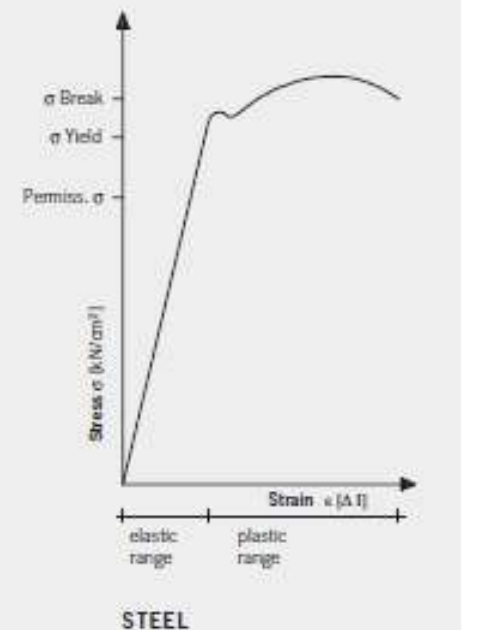

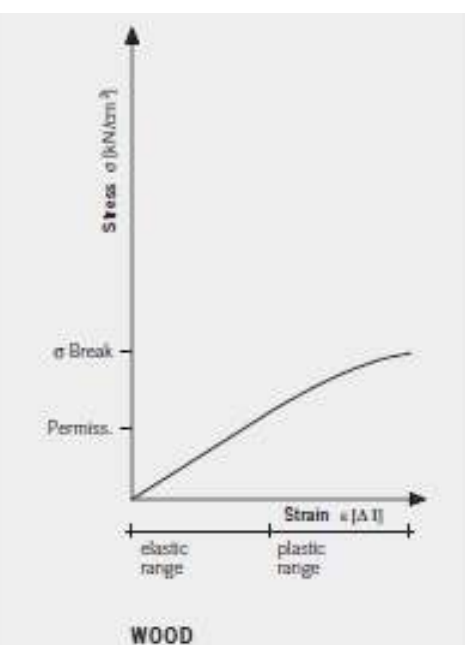

WOOD

Gambar 15. Grafik sifat mekanik kaca dibandingkan bahan lain 


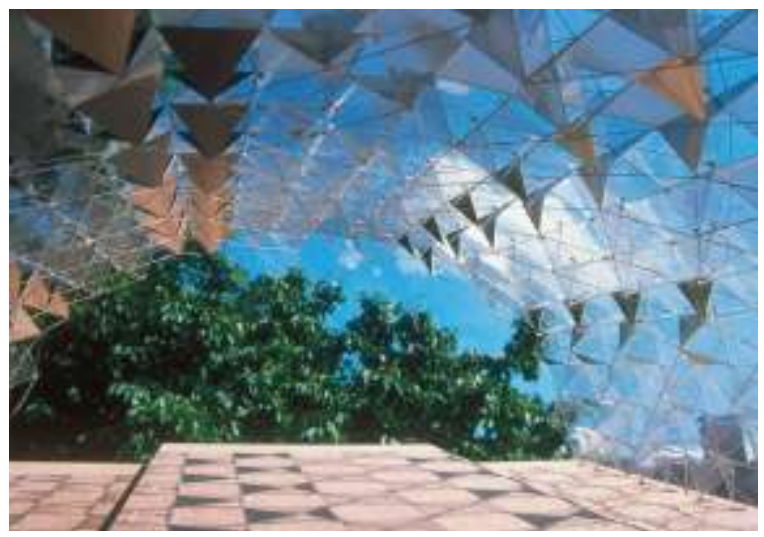

Sumber : (Wurm, 2007)

Gambar 16. Contoh penggunaan kaca sebagai struktur bangunan

\section{Kaca Sebagai Gagasan Konsep Transparansi dalam Arsitektur}

Penggunaan kaca saat ini tidak hanya berfungsi sebagai elemen material pelapis atau penutup bangunan, namun sudah berkembang menjadi bagian atau tataran konsep dalam perancangan arsitektur. Makna penggunaan kaca kini lebih berkembang, tidak hanya melihat kaca sebatas material yang menampilkan kejujuran struktur dan kejujuran fungsionalnya. Kaca hadir untuk menciptakan nilai yang memiliki konektivitas visual dan integrasi antara bangunan, ruang dan lingkungannya. Aplikasi kaca dapat sebagai wujud gagasan konsep transparansi dalam perancangan bangunan.

Gagasan konsep transparansi dalam perancangan bangunan tidak hanya menempatkan proses perancangan yang cepat, murah, efisien dan ekonomis tetapi lebih menitikberatkan pada kemurnian bentuk, bentuk yang lebih ringan, transparan dan mempunyai nilai konteks terhadap lingkungannya. Gagasan konsep transparansi ini diimplementasikan dalam dua metode perancangan yaitu metode fragmentasi dan layering yang keduanya tetap mengintegrasikan kaca sebagai sistem struktur dan material bangunan.

Penggunaan kaca dalam metode fragmentasi adalah mencoba memecah bentuk atau lapisan bangunan utuh sebagai bentuk solid dengan bidang transparan. Menurut Piano (1997) kaca dapat sebagai alat fragmentasi yang bertujuan menghasilkan konsep bangunan yang lebih ringan terhadap lingkup bobot kawasan dan tidak berkesan masif atau solid secara utuh. Penggunaan kaca tidak hanya sebagai bidang tak berbatas tetapi dapat menciptakan keselarasan dengan lingkungan secara fisik dan visual.

Contoh karya aplikasi kaca dengan metode fragmentasi adalah bangunan Renzo Piano Building Workshop (RPBW) yang dirancang pada tahun 1989, sebuah bangunan yang terletak di sisi tebing dan menghadap ke laut (gambar 17). Permukaan sisi bangunan keseluruhan menggunakan kaca, sehingga bangunan ini sangat transparan tiada batasan antara sisi dalam dan luar. Fragmentasi massa bangunan dengan struktur split level yang mengikuti kontur lahan dan penggunaan kaca sebagai bidang lapisan dan permukaan bangunan. Fragmentasi ini bertujuan menghadirkan bangunan yang lebih menyatu dengan konteksnya dan memiliki kesan ringan agar tidak menjadi beban visual bagi lingkungannya. Unsur solid hadir pada bentuk massa bangunan dan unsur transparan pada keseluruhan permukaan bangunan.

Kansai Airport merupakan salah satu bangunan karya Renzo Piano lainnya yang menggunakan metode fragmentasi (Gambar 18). Fragmentasi tidak dilakukan pada massa bangunan utuhnya, namun pada sistem struktur bangunan yang keseluruhannya menggunakan baja. Unsur solid pada struktur bangunan dikombinasikan dengan penggunaan kaca pada sebagian permukaan bangunan, sehingga bangunan tetap terlihat lebih ringan dan terintegrasi secara sistem bangunan. Penggunaan kaca pada permukaan bangunan dapat mempermudah orientasi pergerakan dan memberikan kualitas transparansi secara fisik, khususnya pencahayaan dalam ruangan.

Berbeda dengan dua karya sebelumnya, Museum Louvre di Paris karya I.M Pei tidak menggunakan fragmentasi pada massa bangunan atau sistem struktur tetapi terhadap bangunan yang ada dalam konteks lingkungannya (gambar 19). 


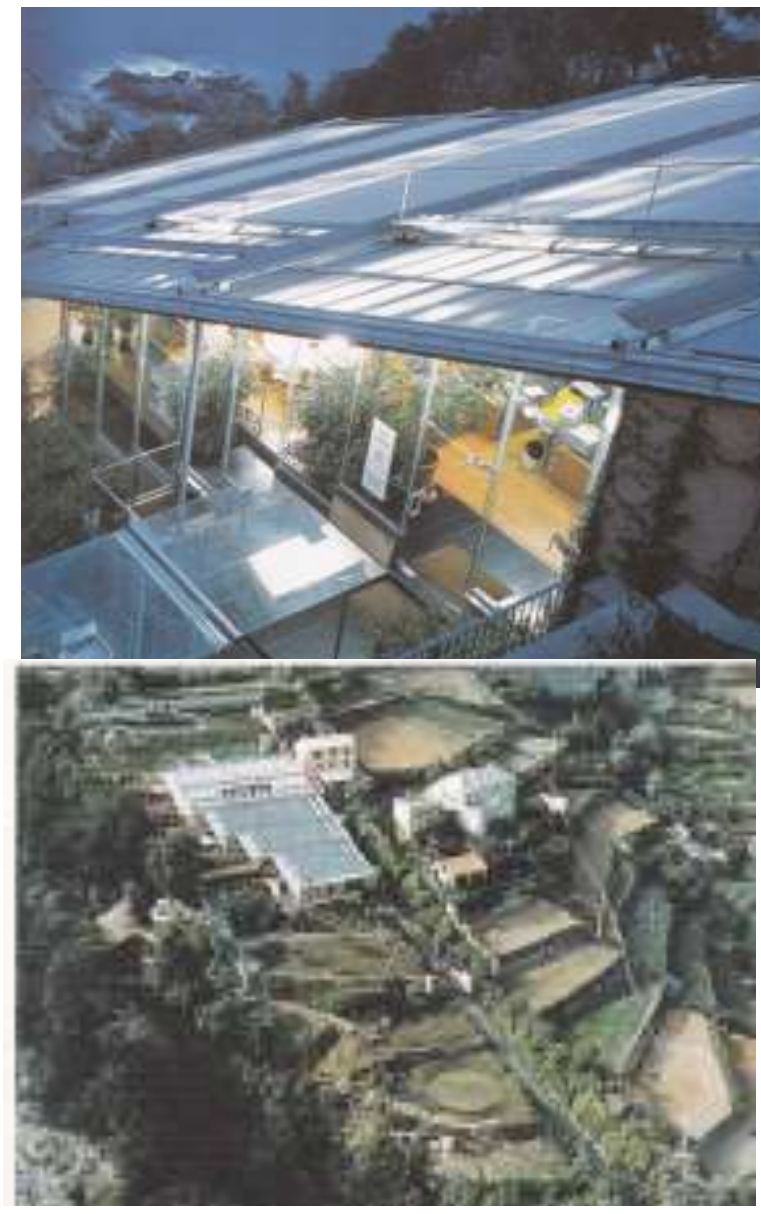

Sumber : (Piano,1997)

Gambar 17. Fragmentasi massa bangunan dan aplikasi kaca pada permukaan bangunan RPBW

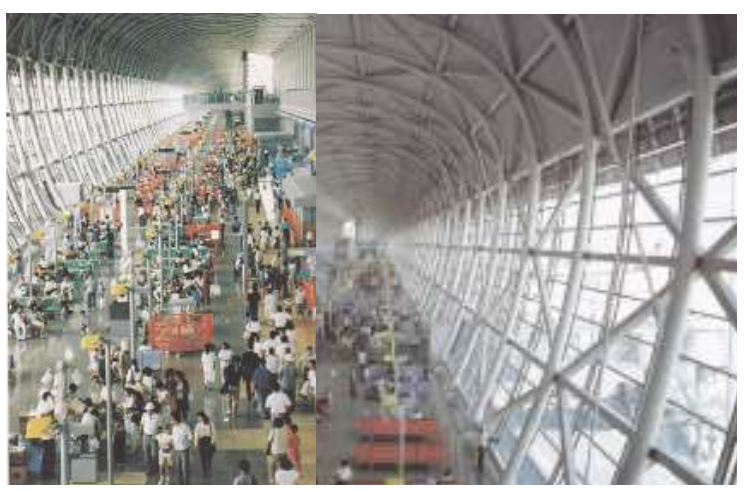

Sumber : (Piano,1997)

Gambar 18. Fragmentasi struktur bangunan dan aplikasi kaca pada permukaan bangunan Kansai Airport

Museum hadir setelah terfragmentasi dari unsur solid bangunan di sekitarnya. Seluruh permukaan entrance bangunan museum menggunakan kaca sebagai bidang transparan yang tidak menghalangi kontinuitas visual antara massa bangunan di sekitarnya. Bangunan mempunyai nilai kontras, namun selaras dengan lingkungannya. Fragmentasi dilakukan berdasarkan massa bangunan disekitarnya dan hadirnya bangunan museum menjadi nilai kontekstual antara bangunan lama dan baru.
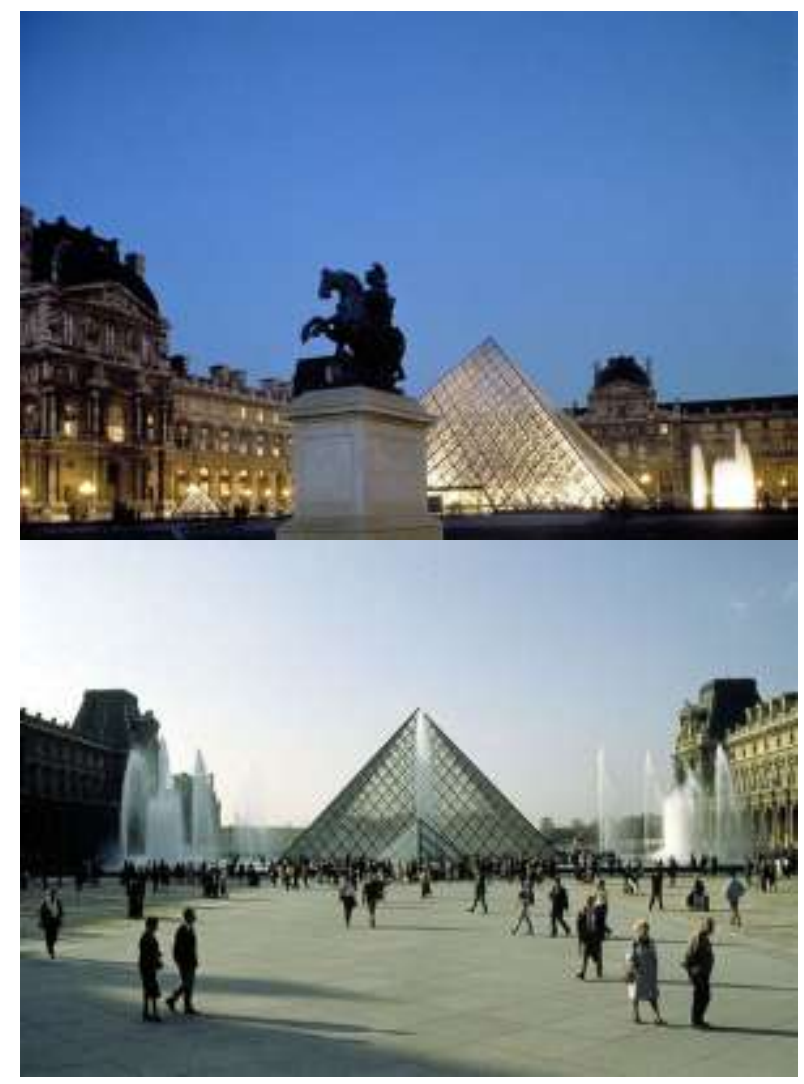

Sumber : http://www.pcf-p.com, akses 9 Juli $2014^{1}$

Gambar 19. Fragmentasi antar massa bangunan pada Museum Louvre

Penggunaan kaca dalam metode layering lebih menekankan pelapisan pada unsur bidang atau bentuk bangunan sebagai elemen pembatas untuk memberikan konektivitas antara ruang dalam dengan luar banguan atau bangunan dengan lingkungannya. Metode ini menitikberatkan strategi pelapisan pada kulit bangunan.

Aplikasi dalam perancangan bisa dilihat pada kasus perancangan Cartier Foundation for Contemporary Art, yang

1 http://www.pcf-p.com/a/p/8315/1.html, gambar suasana ruang luar bangunan Museum Louvre 
dibangun di Paris pada tahun 1994 oleh Jean Nouvel. Bangunan ini berada dalam ruang terbuka yang ditumbuhi pohon-pohon yang besar dan sebagai salah satu tantangan adalah masyarakat tidak mau kehilangan banyak pohon tersebut apabila bangunan itu berdiri. Jean Nouvel mencoba membangun dengan bentuk yang lebih tipis dan vertikal sehingga bangunan tidak hanya berkesan ringan, transparan, namun lapisan bahan kaca yang menutupi permukaan bangunan memberikan ilusi "apakah pohonpohon yang ada dilingkungannya berada di dalam atau di luar bangunan". Aplikasi kaca tidak hanya sebagai kulit bangunan tetapi dapat memberikan hubungan antara bangunan dan lingkungan (gambar 20).
Strategi pelapisan (layering) dengan aplikasi kaca yang memberikan konektivitas antara ruang dalam dan luar dapat dilihat pada karya Glass House oleh Philip Johnson (gambar 21).

Kaca sangat mendominasi permukaan dinding bangunan, bahkan terkesan terbuka seluruh isi bangunan.

Bangunan ini hadir dengan kejujuran struktur dan fungsi, namun elemen kaca ini memberikan makna hubungan tanpa batas antara ruang dalam dan ruang luar bangunan. Alam sebagai dinding bangunan sesungguhnya dan ruang memiliki kualitas visual dan dimensi yang tak terbatas.

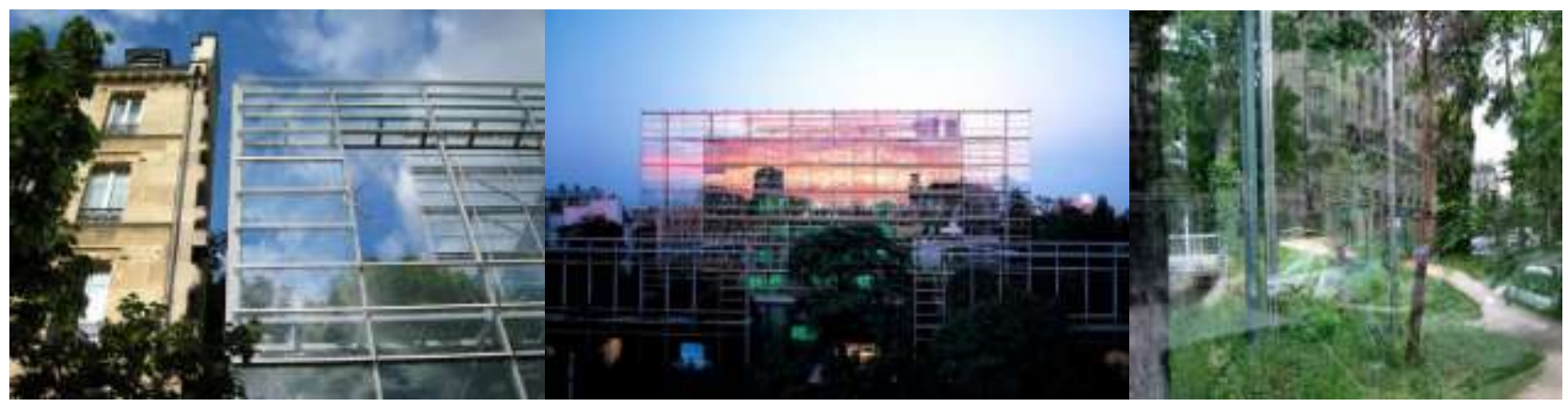

Sumber : http://www.archdaily.com, akses 9 Juli $2014^{2}$

Gambar 20. Layering sebagai strategi konektivitas antara bangunan dengan lingkungan

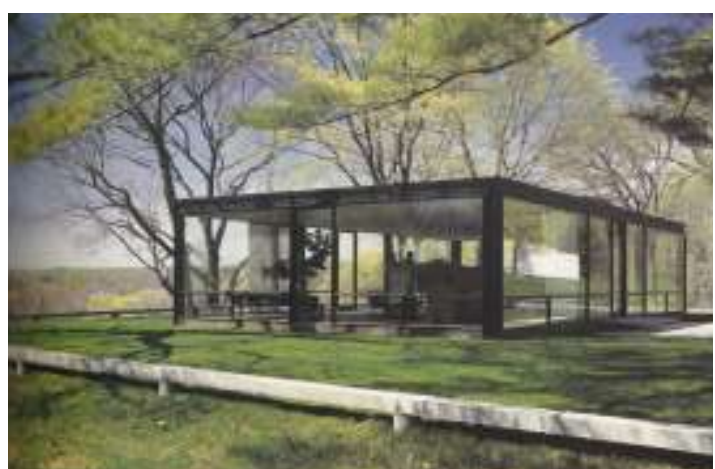

Sumber : Weston, 2002

Gambar 21. Layering sebagai strategi konektivitas antara ruang dalam dan luar bangunan

2 http://www.archdaily.com/84666/ad-classics-fondation-cartier-jean-nouvel/ tentang AD Classics: foundation Cartier/Jean Nouvel 


\section{Kesimpulan}

Kaca merupakan bahan bangunan yang mulai dikenal dan menjadi trend dari arsitektur masa kini. Berbagai sifat dan tipe dari bahan kaca dikembangkan untuk memperoleh sifat yang positif.

Kemampuan dalam menampilkan suatu estetika yang indah didukung oleh sifat yang memiliki ketahanan terhadap panas, tingkat radiasi yang tinggi dan kemampuan akustik dianggap sebagai kelebihan dari bahan kaca.

Kelebihan yang dimiliki material kaca menjadikan material ini dapat dimanfaatkan hampir diseluruh bagian bangunan baik sebagai kulit bangunan maupun struktur.

Berbagai konsep muncul dengan memanfaatkan kelebihan material kaca yang transparan. Konsep transparansi merupakan salah satu contoh gagasan konsep yang muncul dengan memanfaatkan material kaca untuk mendukung konsep kontinuitas visual dan konektivitas antara bangunan dengan lingkungan maupun ruang dalam dengan ruang luar.

\section{Referensi}

Garg, N.K . 2007. Guidelines for Use of Glass in Building. New age international publisher. New Delhi

Piano, R. 1997. The Renzo Piano Logbook. The Monacelli Press. London

Staib, Schittich. 1999. Glass Construction Manual. Birkhauser. Basel, Switzerland.

Weston, Richard. 2002. The House in the $20^{\text {th }}$ Century. Laurence King Publishing Itd. Great Britain

Wurm, Jam. 2007. Glass Structures: Design and Construction of Self-supporting Skins. Birkhauser Verlag AG. Berlin 